represent to your Excellenoy, that our population is now approximating to 100,000 inhabitants, that we have in our midst gentlemen who have long resided in the Tery., been intimately connected with the administration of our laws, and familiar with the internal affairs of our Territory, and under whose auspices as executive officers the public service would be promoted. In view of this the undersigned would very much deprecate the appointment of an executive officer, in this Territory who has not heretofore resided among us-it would jeopard the public interest here, whilst it would cast an unmerited reflection upon the qualifications of our own citizens for that office. Supposing that your Excellency will feel it his duty to assign us a new executive officer we have unitied in recommending our fellow. citizen the Hon. Josepe Williams, who has long been highly and favorably known to the people of this Territory as an individual every way eminently qualified for the post of Governor in this Territory, and whose appointment in our opinion will be highly acceptable to a very large proportion of the people.

If your Excellency will arrest the practice of thrusting upon us strangers and non-residents as our officers, we feel safe in the assertion that you will secure the lasting gratitude of ninety-nine hundredths of all the people in this Territory. Yours, etc.,

W. G. WOODWARD.

Jas. W. Grimes.

Charles Matroon.

I. M. Preston.

J. F. KINNEY.

Steph. Whicher.

Curtis Bateis.

B. S. Roberts.

David Rorer.

S. Hempstead.

A. MoAuley.

R. P. LowE.
S. C. Hastings.

J. d. HALL.

IsAaO V. LEFFLER.

JaMes Crâtford.

T. S. WILSON.

WM. Thompson.

Jameg P. Carleton.

John David.

A. HALL.

T. S. Parvin.

IsAá C. DaY.

\title{
THE IOWA JOURNAL OF HISTORY AND POLITICS.
}

We briefly mentioned this publication in our last number as about to be launched in the place of The Historical Record, at Iowa City. Its first issue appeared early in Janvary. It is an admirably edited and exceedingly well printed magazine of 136 pages, which appears under the auspices of the Iowa State Historical Society. It will be devoted rather to studies and discussions of history and historical literature 
than to the storing up of the materials of history. This first issue presents the following table of contents: "Joliet and Marquette in Iowa," by Laenas Gifford Weld; "The Political Value of State Constitutional History," by Francis Newton Thorpe; "Historico-Anthropological Possibilities in Iowa," by Duren J. H. Ward; "A General Survey of the Literature of Iowa History," by Johnson Brigham. Reviews. of various historical publications, "Notes and Comments," make up the remaining contents of the first number. This journal gives promise of long life and usefulness. It is under the editorial management of Prof. B. F. Shambaugh, whose writings and labors in the expanding field of Iowa history are well known throughout the country, and a sufficient guaranty of the permanence of this new candidate for the public favor. We welcome it to its field of usefulness with all good wishes for its long life and success. It is published quarterly at two dollars per year. Address the State Historical Society of Iowa, Iowa City, Iowa.

\section{IS IOWA'S HISTORY WORTH WHILE?}

One frequently observes in the writings of Iowa's chroniclers an underlying assumption-perhaps one should say presumption-that the history of our State is not especially worth while. This assumption is obvious in the general acquiescence in the notion commonly expressed in conversation that the history of Iowa is not particularly interesting or instructive, that our customs, laws and institutions are neither distinctive nor noteworthy, that our life and scenery are lacking in picturesqueness. In brief, "prosaic" and "matter-of-fact" are the descriptive terms usually applied to our people and to the history of our State.

All Iowans, of course, declare with venemence that Iowa is a magnificent State, that her citizens thrive wonderfully in industry, and her statesmen have played prominent roles in national affairs. But despite all this there is a willingness 
Copyright of Annals of Iowa is the property of State of Iowa, by \& through the State Historical Society of Iowa and its content may not be copied or emailed to multiple sites or posted to a listserv without the copyright holder's express written permission. However, users may print, download, or email articles for individual use. 